\title{
Progression or Regression? - Strengths and Weaknesses of the New Munich Nomenclature III for Cervix Cytology
}

\author{
Progression oder Regression? - Stärken und Schwächen \\ der neuen Münchner Nomenklatur III für die Zervixzytologie
}

Authors

Affiliations
Z. Hilal ${ }^{1}$, C. Tempfer $^{2}$, S. Schiermeier ${ }^{3}$, J. Reinecke ${ }^{2}$, C. Ruppenkamp ${ }^{2}$, Z. Hilal ${ }^{4}$

${ }^{1}$ ZYDOLAB - Institut für klinische Zytologie und Immunzytochemie, Dortmund

${ }^{2}$ Abteilung für Gynäkologie und Geburtshilfe, Ruhr Universität Bochum, Herne

${ }^{3}$ Abteilung für Gynäkologie und Geburtshilfe, Universität Witten/Herdecke, Witten

${ }^{4}$ Institut für Pathologie, Universitätsklinikum Düsseldorf, Düsseldorf

\section{Key words \\ - cervical intraepithelial neoplasia \\ - cervix cytology \\ - Munich nomenclature III \\ - cancer screening \\ - dysplasia \\ Schlüsselwörter \\ - zervikale intraepitheliale Neoplasie \\ - Zervixzytologie \\ - Münchner Nomenklatur III \\ - Krebvorsorge \\ - Dysplasie}

Deutsche Version unter: www.thieme-connect.de/ ejournals/gebfra

\section{received 23.3.2015 \\ revised 11.6.2015 \\ accepted 12.6.2015}

\section{Bibliography}

DOI http://dx.doi.org/

10.1055/s-0035-1557904

Geburtsh Frauenheilk 2015; 75 :

1051-1057 @ Georg Thieme

Verlag KG Stuttgart · New York

ISSN 0016-5751

\section{Correspondence}

\section{Dr. med. Ziad Hilal}

ZYDOLAB - Institut für

klinische Zytologie und

Immunzytochemie

Markt 10

44137 Dortmund

z.hilal@zydolab.de

\section{Abstract}

\section{$\nabla$}

Introduction: Since 01.01.2015 the new Munich nomenclature III for gynaecological diagnostics of the cervix has been in force. The changes have led to controversial scientific discussions. This study reports for the first time on the consequences.

Materials and Methods: The present data are based on smear screening results for the year 2014. The data of 63134 patients were evaluated. Results: $2.27 \%$ of all smears were remarkable. Group Ila was assigned to $0.91 \%$. Group II-p was somewhat more frequently recorded than group IIID1 ( 0.59 vs. $0.53 \%)$. Groups IIID1 and IIID2 were found in 0.53 and $0.61 \%$, respectively, of the cases. Agreement with histology was found in 36.84 and $44.68 \%$, respectively. Glandular lesions represented the most frequent changes in group III. Histological clarification was obtained for $0.18 \%$ of all remarkable findings. The relative incidence of high-grade precancerous conditions (CIN III) and invasive tumours amounted to $0.1 \%$.

Conclusion: A close communication between gynaecologists and cytologists is mandatory for the correct usage of the new nomenclature. The future annual statistics of the health insurances can now be analysed in more detail. A statistical classification of glandular epithelial changes is now also possible for the first time. The heterogeneous group Ila constitutes an unnecessary uncertainty for patients and physicians. The splitting of the group IIID does not appear to have any advantage for the further clinical management. Further studies are needed to show whether or not the classification can stand up to international comparisons.

\section{Zusammenfassung \\ $\nabla$}

Einleitung: Seit dem 01.01.2015 wird die Neue Münchner Nomenklatur III für die gynäkologische Zytodiagnostik der Cervix uteri eingesetzt. Die Änderungen führten zu kontroversen wissenschaftlichen Auseinandersetzungen. Diese Studie berichtet nun erstmalig über die Auswirkungen. Material und Methoden: Die vorliegenden Daten beziehen sich auf die Screeningabstriche aus dem Untersuchungsjahr 2014. Die Daten von 63134 Patientinnen konnten ausgewertet werden.

Ergebnisse: 2,27\% aller Abstriche waren auffällig. Die Gruppe Ila wurde in $0,91 \%$ vergeben. Die Gruppe II-p wurde etwas häufiger als die Gruppe IIID1 erfasst (0,59 vs. 0,53\%). Die Gruppen IIID1 und IIID2 kamen in 0,53 bzw. 0,61\% der Fälle vor. Eine Übereinstimmung mit der Histologie fand sich in 36,84 bzw. 44,68\%. Glanduläre Läsionen stellten die häufigsten Veränderungen in der Gruppe III dar. Histologische Klärung erfolgte in 0,18\% aller auffälligen Befunde. Die relative Häufigkeit hochgradiger Präkanzerosen (CIN III) und invasiver Tumore betrug $0,1 \%$.

Schlussfolgerung: Eine enge Kommunikation zwischen Frauenarzt und Zytologe ist für die korrekte Anwendung der neuen Nomenklatur unverzichtbar. Zukünftige Jahresstatisitiken der KVen können nun detaillierter ausgewertet werden. Erstmalig ist auch eine statistische Einordnung drüsenepithelialer Veränderungen möglich. Die heterogene Gruppe Ila stellt eine unnötige Verunsicherung für Patientinnen und Ärzte dar. Die Aufteilung der Gruppe IIID scheint keinen Vorteil für das weitere klinische Management darzustellen. Ob eine internationale Vergleichbarkeit der Klassifikation gewährleistet ist, müssen weitere Studien zeigen. 


\section{Introduction}

\section{$\nabla$}

With an incidence of $2.2 \%$ of all new cancer diseases in women, cervical cancer belongs among the less common organ malignancies in Germany. In parallel to the introduction of Papanicolaou staining [1] as a cytological screening test of the uterine cervix, there was a marked decline of $80 \%$ in the incidence of cervical cancer in Germany. For 2012 with an annual number of participants of more than 16 million women, 4600 new cases (9.0/ 100000 women) are expected [2].

Since 1990 the cytological evaluation of cervical smears in Germany has been based on the Munich nomenclature II. This consists of 5 groups (PAP I-V), which describe the widely varying degrees of dysplasia ranging through to invasive carcinoma [3].

On account of the newest findings on the tumour biology of cervical cancer and the increased demands on the sensitivity of screening methods together with the marked decline in the incidence of the disease, the nomenclature has been revised by the Cytology Coordination Conference (KoKoZyt) and was published at the beginning of 2014 [4]. This nomenclature is legally binding in Germany since 01.01.2015 [5].

The changes are listed below:

- with retention of the groups I to V, subgroups have been introduced

- suffixes in the subgroups show the type of epithelium concerned

- group IIID has be further divided into IIID1 and IIID2

- a new group "Ila" has been created for patients with unremarkable smears but with remarkable case history/clinical findings - group II has been redefined [4].

The agreed new features in the Munich nomenclature III have in part been met with strong resistance and have already led to controversial discussions [6-9]. Against the background of possible far-reaching changes in cancer screening for the uterine cervix within the framework of the National Cancer Plan [10], a critical discussion of the new Munich nomenclature III is called for.

\section{Aim}

$\nabla$

Up to now there have been no comprehensive evaluations of the new Munich nomenclature III for gynaecological-cytological diagnostics of the uterine cervix. A confrontation between the old and new nomenclatures with comparisons of statistical distributions has not yet been undertaken. In particular, data for the correlation between cytological findings and histological results have not been examined.

The aim of this study was to carry out an analysis of statistical findings according to the new nomenclature and to illustrate the consequences in comparison with the old nomenclature. In addition, a detailed consideration of the individual categories of finding as well as a correlation of cytological smears requiring clarification with the results of histological samples have been undertaken. Finally, the statements postulated by the KoKoZyt about the statistical frequencies of the individual groups of findings were checked.

\section{Material and Methods}

$\nabla$

\section{Data acquisition}

The Cytological Institute ZYDOLAB in Dortmund is a clinical laboratory with a supra-regional patient collecting area. It represents a cross-section of the women participating in cervix screening in Germany. Screening diagnosis for cervical cancer in Germany is available once per year for women aged 20 years and over and comprises a gynaecological examination of the female genitalia with a smear test and subsequent cytological evaluation. The data for the present study are from gynaecological smear screening tests performed in 2014. For this purpose all samples taken between January and December 2014 and sent to the cytological institute ZYDOLAB in Dortmund within the framework of cancer screening were taken into consideration. So-called "curative" smears, i.e., control smears taken in the same year do not count here in the sense of health insurance benchmarking according to the guidelines for quality assurance of the German Medical Association [11]. Furthermore, all histological findings reported to the institute up to February 2015 for cases of cytology requiring further clarification were also considered. The study was approved by the Ethics Commission of the Ruhr University Bochum (Register No. 5189-14).

\section{Cytological diagnostics and statistical analysis}

The smears taken from the uterine cervix in the course of cancer screening were stained according to the method of Papanicolaou [1] and subsequently evaluated by an experienced examiner according to the standards for quality assurance measures of the German Medical Association [6]. Since publication of the new Munich nomenclature III in January 2014 evaluation of the samples in the laboratory was carried out according to the old and the new nomenclature. The data were recorded with the help of a software programme (Pegasus Datensysteme, Munich). Remarkable samples were first screened by at least 2 further assistants and then evaluated by 2 further medical experts and subsequently classified.

In the framework of the present study, in addition, findings including age of the patient, remarkable previous findings, additional clinical details, relevant prior diseases and histology results for findings needing clarification were anonymised and entered in a Microsoft Excel data base (Microsoft Corporation, Redmond, USA) and statistically analysed with the help of functions in Microsoft Excel and SPSS (International Business Machines Corporation [IBM], Armonk, USA).

\section{Results}

$\nabla$

Altogether data from 63134 patients were acquired. The average age of the patients amounted to 42.9 years (median 42 years, range 20-99 years). The number of patients who had undergone a total hysterectomy was 7835 (11.7\%).

- Table 1 illustrates the statistical evaluation of the smear findings according to the old nomenclature as well as the corresponding results according to the new nomenclature. Altogether 67 samples $(0.11 \%$ of all samples) could not be classified or could only be classified with limitations. The reasons for this were an inadequate fixation, too little or even no cell material, extended artificial or severe degenerative cell changes and massive cell overlaps. 
Table 1 Distribution of smear findings according to PAP groups in the framework of cancer screening of the uterine cervix according to age (Munich II) and the corresponding results according to the new nomenclature (Munich III) in a screening collective from the year $2014(n=63134)$.

\begin{tabular}{|c|c|c|c|c|c|}
\hline $\begin{array}{l}\text { Munich } \\
\text { II }\end{array}$ & $n$ & $\%$ & $\begin{array}{l}\text { Munich } \\
\text { III }\end{array}$ & $n$ & $\%$ \\
\hline $\begin{array}{l}\text { techni- } \\
\text { cally not } \\
\text { usable }\end{array}$ & 67 & 0.11 & 0 & 67 & 0.11 \\
\hline \multirow[t]{2}{*}{ I } & 618 & 0.98 & I & 61122 & 96.81 \\
\hline & & & Ila & 576 & 0.91 \\
\hline \multirow[t]{4}{*}{ II } & 61604 & 97.58 & ॥ & 524 & 0.83 \\
\hline & & & $-p$ & 370 & 0.59 \\
\hline & & & g- & 132 & 0.21 \\
\hline & & & -e & 22 & 0.03 \\
\hline \multirow[t]{5}{*}{ III } & 88 & 0.14 & III & 88 & 0.14 \\
\hline & & & $-p$ & 22 & 0.03 \\
\hline & & & $-g$ & 60 & 0.10 \\
\hline & & & -e & 2 & $<0.01$ \\
\hline & & & $-x$ & 4 & 0.01 \\
\hline \multirow[t]{2}{*}{ IIID } & 720 & 1.14 & IIID1 & 335 & 0.53 \\
\hline & & & IIID2 & 385 & 0.61 \\
\hline \multirow[t]{3}{*}{ IVa } & 28 & 0.04 & IVa & 28 & 0.04 \\
\hline & & & $-p$ & 26 & \\
\hline & & & $-g$ & 2 & \\
\hline \multirow[t]{3}{*}{$\mathrm{IVb}$} & 2 & $<0.01$ & $\mathrm{IVb}$ & 2 & $<0.01$ \\
\hline & & & $-p$ & 2 & \\
\hline & & & -g & 0 & \\
\hline \multirow[t]{5}{*}{ V } & 7 & 0.01 & V & 7 & 0.01 \\
\hline & & & $-p$ & 5 & \\
\hline & & & -g & 2 & \\
\hline & & & $-e$ & 0 & \\
\hline & & & $-x$ & 0 & \\
\hline
\end{tabular}

\section{PAP I/II}

Group I according to the old nomenclature was assigned in 618 cases $(0.98 \%)$. According to the new nomenclature this makes group I with 61122 cases (96.81\%) by far the most frequent group.

In comparison, group II was assigned 61604 times (97.58\%) according to the old nomenclature and thus represents the most frequent group. According to the new nomenclature group was, with a total of 524 cases $(0.83 \%)$, in comparison markedly less frequently assigned.

\section{PAP II a}

The newly defined group Ila in the Munich nomenclature III was assigned in 576 cases $(0.91 \%)$ ( 0 Table 2 ). The most frequent reason for assignment of a smear sample to this group was, in 484 cases $(84.17 \%)$ the cytological or histological detection of mild or moderate dysplasia on squamous epithelium of the cervix (group IIID1/2 or, respectively, CIN I/II) in the previous gynaecological examination.
Table 2 Group Ila according to the Munich nomenclature III $(n=576)$. Case history and clinical details for the smear samples in absolute and relative frequencies.

\begin{tabular}{|c|c|c|}
\hline Remarkable case history & $\begin{array}{l}\text { Absolute } \\
\text { frequency }\end{array}$ & $\begin{array}{l}\text { Relative } \\
\text { frequency (\%) }\end{array}$ \\
\hline $\begin{array}{l}\text { Status after PAP IIID1/2 or } \\
\text { histological detection of CIN I/II }\end{array}$ & 484 & 84.03 \\
\hline Status after PAP III & 57 & 9.89 \\
\hline $\begin{array}{l}\text { Status after PAP IV or detection } \\
\text { of CIN III by PE or conisation }\end{array}$ & 27 & 4.69 \\
\hline Clinical/colposcopic abnormalities & 5 & 0.87 \\
\hline $\begin{array}{l}\text { Status after PAP V or, respectively, } \\
\text { detection of an invasive cancer }\end{array}$ & 3 & 0.52 \\
\hline
\end{tabular}

\section{PAP II}

Group II according to the new nomenclature describes findings that have "limited protective value". The collective of group II-p patients with an average age of 34.8 years was markedly younger than the entire collective $(p<0.0001)$. The classification of a sample to group II-p was made from a morphological point of view in 305 cases $(82.4 \%$ ) on the basis of koilocytic or horny changes in cytoplasm with only minor changes of the nucleus which were interpreted as a sign of HPV infection (@ Table 3). On the other hand, 65 samples (17.6\%) were classified as "II-p" on the basis of nuclear enlargements of squamous epithelium with mild dysplasia and changes of core shape in inflammatory cell pictures.

According to the new nomenclature the group II-g describes "cervical gland cells with anomalies that range beyond the spectrum of reactive changes". In the present collective this was the case in 132 patients $(0.21 \%)$. For a total of 29 patients $(21.96 \%)$ a control smear was performed during the data collection period. 28 (96.55\%) of these smear controls were inconspicuous and in one case (3.45\%) pronounced atypia of the cervical gland epithelium (III-g) were detected in the control smear. On histology a polyp of the cervix was diagnosed.

In group II-e according to the new nomenclatures, unremarkable endometrial cells found in the second half of the menstrual cycle of women over 40 years of age are collected together. In the present collective the smears of 22 patients $(0.03 \%)$ were assigned to this group. Of these patients, 16 had perimenopausal and 2 postmenopausal statuses. The latter 2 women underwent a histological examination by fractional abrasion which was unremarkable in both cases. In 4 further cases unremarkable endometrial cells were found in the second half of the cycle of premenopausal women.

\section{PAP III}

O Fig. 1 illustrates the 88 cases ( $0.14 \%$ of all sample) unclear or, respectively, equivocal findings (group III) and the results of their further clarification. Histological clarification was carried out in 12 cases (13.6\%) ( $\boldsymbol{O}$ Fig. 2 ). Thereby for the 11 cases of a cytologically identified III-g sample, the following histological diagnoses

Table 3 Group II-p according to the Munich nomenclature III. Age distribution, HPV signs and changes on inflammation $(n=370)$.

\begin{tabular}{lllllll} 
Age group in years & $\mathbf{n}$ & \% & HPV signs $(\mathbf{n}=\mathbf{3 0 5})$ & $\%$ & Changes on inflammation $(\mathbf{n}=\mathbf{6 5})$ & \% \\
$<36$ & 221 & 59.73 & 210 & 68.85 & 11 & 16.92 \\
\hline $36-50$ & 119 & 32.16 & 93 & 30.49 & 26 & 40.00 \\
\hline 50 & 30 & 8,11 & 2 & 0.66 & 28 & 43.07 \\
\hline
\end{tabular}




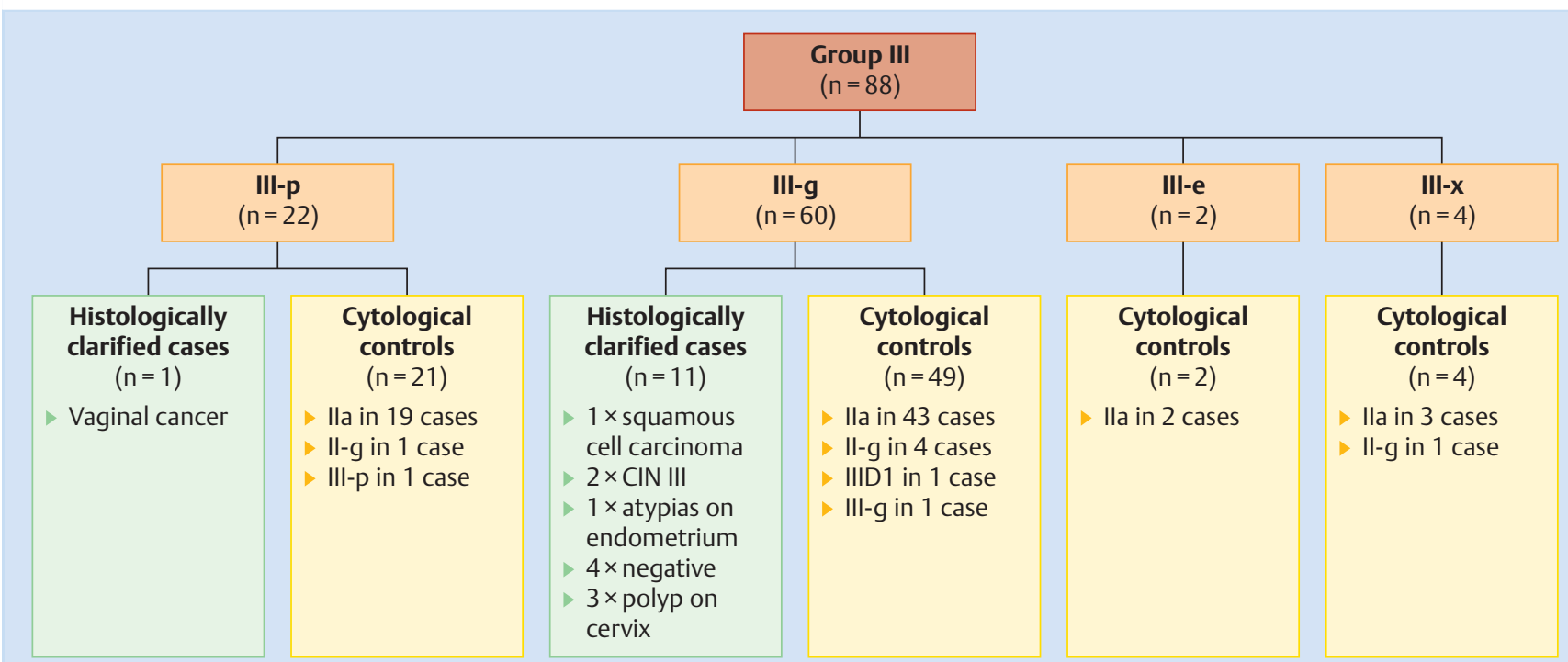

Fig. 1 Clarification of 88 cases with unclear or equivocal findings according to the Munich nomenclature III, ordered according to histologically clarified cases $(n=12)$ and cytological follow-up controls $(n=76)$.

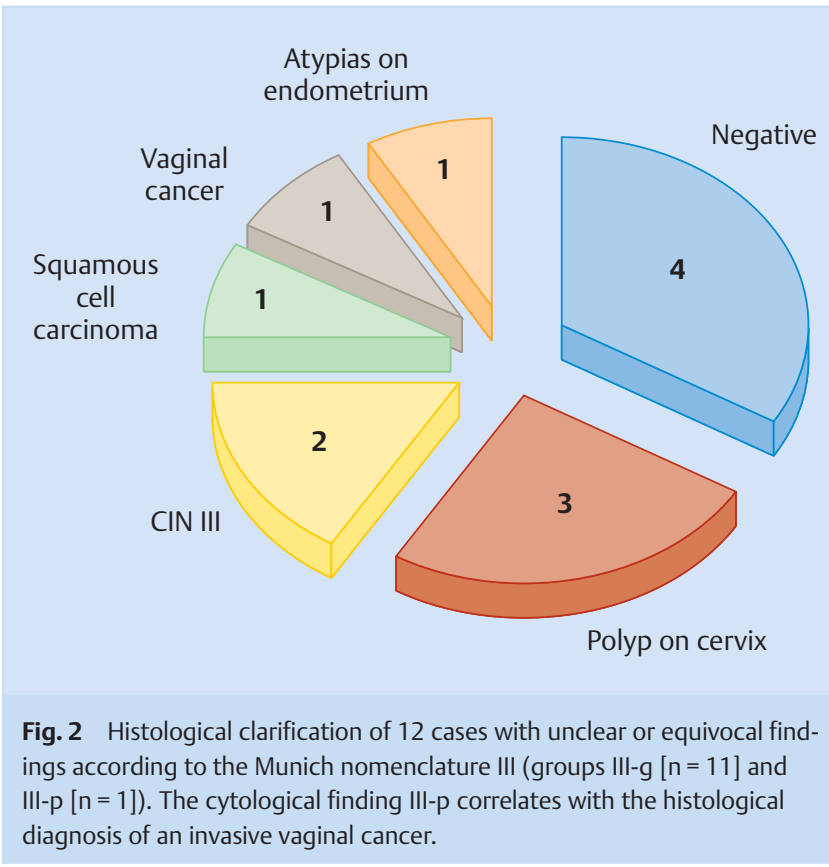

were deduced: inflammatory changes $(n=4)$, polyp of the uterine cervix $(n=3)$, severe dysplasia of the squamous epithelium $(\mathrm{n}=2)$, squamous cell carcinoma $(\mathrm{n}=1)$ and atypical changes in endometrial cells $(n=1)$. In one of the samples assigned as III-p the diagnosis of a vaginal cancer was confirmed.

\section{PAP IIID}

Among the total of 720 samples that were classified as IIID according to the old nomenclature, 335 (46.53\%) were assigned to group IIID1 and 385 (53.47\%) to group IIID2 according to the new nomenclature. Histological clarification was performed in 66 cases (9.17\%). O Table 4 gives an overview of the histology results.
Table 4 Mild and moderate dysplasias (groups IIID1 and 2 according to the Munich nomenclature III) and correlation with histology in absolute and relative frequencies $(n=66)$.

\begin{tabular}{|llccc|} 
& $\begin{array}{l}\text { IIID1 } \\
\text { (n= 19) }\end{array}$ & \% & $\begin{array}{l}\text { IIID2 } \\
(\mathbf{n = 4 7 )}\end{array}$ & \% \\
\hline Negative & 6 & 31.58 & 2 & 4.26 \\
\hline CIN I & 7 & 36.84 & 9 & 19.14 \\
\hline CIN II & 4 & 21.05 & 21 & 44.68 \\
\hline CIN III & 2 & 10.52 & 15 & 31.91 \\
\hline Invasive cancer & 0 & 0 & 0 & 0 \\
\hline
\end{tabular}

Table 5 Severe dysplasias (group IV according to the Munich nomenclature III) and correlation with histology in absolute and relative frequencies $(n=30)$.

\begin{tabular}{|l|llll|} 
& $\begin{array}{l}\text { IVa-p } \\
\text { (n=26) }\end{array}$ & $\begin{array}{l}\text { IVa-g } \\
(\mathbf{n}=\mathbf{2})\end{array}$ & $\begin{array}{l}\text { IV } \mathbf{b}-\mathbf{p} \\
\mathbf{( n = 2 )}\end{array}$ & $\begin{array}{l}\text { IV } \mathbf{~}-\mathbf{g} \\
\mathbf{( n = 0 )}\end{array}$ \\
\hline Negative & 1 & 0 & 0 & - \\
\hline CIN I & 0 & 0 & 0 & \\
\hline CIN II & 3 & 0 & 0 & \\
\hline CIN III & 22 & 1 & 2 & \\
\hline Invasive squamous & 0 & 1 & 0 & \\
cell carcinoma & & &
\end{tabular}

Thereafter microscopic tissue examinations revealed IIID1 in 19 cases $(5.67 \%)$ and IIID2 in 47 cases (12.21\%).

\section{PAP IV/V}

Thirty samples $(0.05 \%)$ were classified by cytology as PAP IV ( Tab. 5). Of these, 26 samples were assigned to the group IVa$\mathrm{p}$ according to the new nomenclature. Histologically these findings correlated with CIN III in 22 cases. The cytological finding "V" was assigned in 7 cases (0.01\%). Hereby in the 5 cases of V-p according to the new nomenclature, the diagnosis of an invasive squamous cell carcinoma was made 4 times and the diagnosis of a severe dysplasia (CIN III) was made once by histology. In the 2 cases of $\mathrm{V}$-g, there was one diagnosis each of an invasive squa- 
mous cell carcinoma and an invasive adenocarcinoma, respectively.

\section{Discussion}

Since 01.01.2015 the Munich III nomenclature for gynaecological cancer screening of the uterine cervix [5] has replaced the previously used classification scheme according to Munich II [3]. In accord with the agreement on quality assurance measures postulated by the German Medical Association [5] it is now obligatory to report the findings of smear tests according to Munich III. The basic skeleton of the classification of findings into the groups I-V according to Munich II remains intact. A first decisive change is the new definition of group II: this now exclusively encompasses cell pictures that represent a potential risk for the development of dysplasias and for which the "protective value is limited". This major change is also reflected clearly in the statistics of the present collective: according to the old nomenclature group I would have been assigned to merely $0.98 \%$ of all screening examinations, while this is the case in $96.81 \%$ according to the new nomenclature. If we include the newly created group II as well, altogether $97.73 \%$ of all cell pictures could be classified as inconspicuous. On the other hand, the heterogeneous group II according to the old nomenclature represents $97.58 \%$ of all smear examinations without differentiating between changes that have a potential risk for the development of dysplasias and those that do not. According to the new nomenclature, the differentiated consideration now results in group II being assigned to $0.83 \%$ of all screening cases.

The Munich nomenclature III includes the newly created group IIa. This group describes "unremarkable findings with a remarkable case history". A remarkable case history means a conspicuous cytology or histology finding in the previous examination. Similarly, conisation with detection of dysplasia in the resection margins and abnormalities on colposcopy ("major changes") are considered to be conspicuous features. Only when group IIa has been assigned twice in succession a subsequent classification as group I again is possible. On the other hand, the following constellations do not justify an assignment to group Ila: a conisation with dysplasia-free resection margins, follow-up due to cervical or vaginal cancer or VAIN, the isolated detection of a positive high-risk HPV test or malignancy in a neighbouring localisation (e.g., endometrial cancer) [12]. In our collective, $0.91 \%$ of all screening examinations were assigned to group IIa. By far the most frequent reason for assignment of a finding to group IIa was the cytological or histological detection of a mild to moderate dysplasia of cervical squamous epithelium (group IIID1/2 or, respectively, CIN I/II) in the previous gynaecological examination, amounting to $84.17 \%$ for this patient collective. In less than $1 \%$ did the current clinical details such as, e.g., abnormalities on colposcopy, allow assignment of an unremarkable finding to group IIa. Since the responsible cytologist is very heavily dependent on receiving exact details from the clinician in the finding group Ila, the authors consider this newly created group to be problematic. Furthermore, this finding category represents a heterogeneous group with varying oncogenic potential that cannot be defined exactly and that is also not provided for in the commonly used international Bethesda nomenclature [13] and thus cannot be compared with the latter.

A further innovation is the introduction of suffixes that enable the recognition of the suspicious cell type in the smear. The newly defined group II is accordingly divided into subgroups. The most frequent subgroup was group II-p that was assigned in $0.59 \%$ of all screening examinations. This group describes especially mature squamous cells that under the influence of a HPVmediated infection of the epithelium, present koilocytic cytoplasm changes or dyskeratocytes but without showing nuclear changes - as with a mild dysplasia. In the great majority of cases this affects young women aged between 20 and 35 years which can be explained by the high prevalence of HPV infections of up to $50 \%$ in this age group $[14,15]$. However, the authors also have seen nuclear changes in squamous cells in inflammatory cell pictures that cannot be explained only on the basis of a reactive change and behind which also dysplastic changes may be concealed in group II-p.

Group II-g of the new nomenclature describes cervical gland cells with "anomalies that range beyond the spectrum of reactive changes". In the present collective these amounted to $0.21 \%$ of all screening examinations. Frequent changes that justify the assignment to group II-g are polyps on the uterine cervix, changes due to smear tests (brush biopsies) or a contraceptive spiral in utero. Dysplastic changes in connection with an assignment to group II-g were not observed in our collective.

In group II-e of the new nomenclature are collected unremarkable endometrial cells found in cervical smears collected from women over 40 years of age in the second half of their menstrual cycles. In the present collective this group constituted $0.03 \%$ of all examined samples. In the great majority of the cases these are women in the perimenopausal phase of their lives. In this context, Moroney et al. described a higher risk for uterine pathologies [16]. For postmenopausal patients the risk for uterine neoplasias increases markedly to $10 \%$ [17]. As in our collective, the general experience is that exact details of the last menstruation are lacking so that a precise classification in this finding group is very often not possible. Group III evaluates "unclear and equivocal" changes among which high-degree dysplasias (> CIN 2) or invasive cancers cannot be excluded with certainty. Altogether, this group was represented with an incidence of $0.14 \%$ in the screening. Up to date a precise statistical evaluation of the actual lesions in group III has not been possible. With the help of the suffixes exact assignments can now be made. It now appears that glandular lesions represent the most frequent changes in group III $(0.1 \%$ in the screening). Accordingly, abnormal glandular epithelial changes (II-g and III-g) were detected in $0.30 \%$ of all screening smears. In our collective unclear changes of immature squamous epithelium occurred in $0.03 \%$ of the cases and confirmed the conclusions of KoKozyt and other authors on the statistical frequency of this group $[18,19]$. Histological clarification was realised in a total of $13.6 \%$ of the cases whereby unclear alterations on glandular epithelium (III-g) were clarified in the great majority of the cases. High-degree dysplasias (> CIN 2+) and invasive cancers were diagnosed in total in $5.6 \%$ of all examined samples. It was confirmed in our collective thereby that high-degree dysplasias (> CIN 2+) and invasive cancers are more common with glandular changes than with squamous epithelial lesions (6.67 vs. $4.54 \%$ ). However, these figures differ markedly from conclusions of the KoKoZyt according to which high-degree lesions and invasive cancers can be expected for about $75 \%$ of the samples classified as III-g and for about $35 \%$ of those classified as III-p [18]. On the one hand, this discrepancy can be explained by the fact that not all histologically clarified cases were forwarded to the cytology laboratory within the framework of acquired annual statistics. On the other hand, only data for the year 2014 were an- 
alysed. It can be assumed, however, that the actual figures are higher. In this context the future annual statistics of the health insurances will clarify the matter and it will be possible to exactly define the risks of the respective subgroups.

Corresponding to the differing remission rates [20-23], group IIID is subdivided in the Munich III system.

Thus, in the screening collective, IIID1 and group IIID2 findings occurred in $0.53 \%$ and, respectively, $0.61 \%$ of the cases. Accordingly, the screening group II-p was assigned somewhat more frequently than the group IIID1 ( 0.59 vs. $0.53 \%)$. These data thus do not agree with the statement that "in screening the case number in group II-p should be markedly lower than that in group IIID1" [18]. This is also not to be expected because the HPV prevalence is on the whole very high $[24,25]$, but, at the same time, there is a high potential for regression [26]. Group II-p thus emphasises the biological significance of HPV infection as being reversible. In the old nomenclature the unofficial groups "IIw" or "IIk" were often used for this situation, but they do not appear in any statistics and their definitions are not clear.

Histological clarification of dysplastic findings, as to be expected, was less frequently carried out for mild dysplasias than for moderate dysplasias (5.67 vs. $12.21 \%$ ). A correct agreement between cytology and histology was seen in merely $36.84 \%$ (CIN I) or, respectively, $44.68 \%$ (CIN II) of all findings. In $32 \%$ of all cases a higher grade of dysplasia was found. Accordingly, clinical management should not be based solely on the cytological cell picture. The available data thus call into question the recommended clinical management according to which a differential colposcopic examination is indicated after 12 or, respectively, 6 months in cases of IIID1 or IIID2 findings [18]. Evidence-based data in support of this procedure from prospectively examined collectives are still lacking. Moreover, a nomenclature defines and names specific categories of findings. Without consideration of further important factors such as, e.g., age or HPV status, clinical management cannot be based on the cytological cell picture alone. The formulation of clinical algorithms is rather a task for evidence- and consensus-based guidelines.

In our collective, group IV was assigned in $0.05 \%$ of the cases, mostly squamous cell dysplasias (28 of 30 ) were described. With the exception of one case, cytology correlated with the histological diagnosis of severe dysplasia or, respectively, an invasive cancer. The differentiation between moderate and severe dysplasias of the squamous epithelium is thus meaningful. Accordingly the further management procedure should differ from each other. In comparison with the Bethesda nomenclature [13], the new Munich nomenclature has an advantage in such a situation in that moderate (IIID2) and severe changes (IV) are not grouped together. Thus over-therapy in the form of conisation can be avoided.

Furthermore, glandular lesions are also included in group IV. Only in this way will it be possible in future to handle the increasing number of adenocarcinoma in situ cases [27-29].

Finally, group V describes invasive cancers. In these cases also, the origin of the cellular changes is more exactly described by the use of suffixes so that, in future, an exact statistical treatment will be possible.

Overall it is fair to say that according to the new nomenclature, $2.17 \%$ of all screening examinations presented abnormalities in the sense of cancer prevention whereas the exact number according to the old nomenclature cannot be determined on account of the heterogeneous group II. The histological clarification rate of conspicuous findings amounted to $0.18 \%(n=117)$. The relative incidences of severe precanceroses (CIN III) and invasive tumours amounted to $0.1 \%(n=60)$. The Pap test in women without a uterine cervix is of no use [30]. With more than one in every 10 patients, the rate of women who had undergone a total hysterectomy but still participated in the screening is surprisingly high. Accordingly in Germany as well as in other industrialised countries the appropriate recommendations are not being followed [31].

\section{Conclusions}

$\nabla$

Close communications between the gynaecologist and the cytologist are indispensable for the correct usage of the new nomenclature. It will be possible to analyse future annual statistics of the health insurances in more detail. The heterogeneous group Ila represents an unnecessary source of uncertainty for patients and physicians. The statistical classification of glandular epithelial changes is now possible for the first time. The division of group IIID does not appear to have any advantages for the further clinical management. Whether or not an international comparison of the classifications is guaranteed must be investigated in further studies.

\section{Acknowledgements}

$\nabla$

Dr. Ziad Hilal is grateful to the cytology assistants for the always highly motivated and meticulous work-up of the cytology smears.

\section{Conflict of Interest \\ $\nabla$}

None.

\section{References}

1 Papanicolaou GN. Diagnosis of uterine Cancer by the vaginal Smear. New York: The Commonwealth Fund; 1943

2 Robert Koch-Institut. Krebs in Deutschland 2007/2008. Häufigkeiten und Trends. 8. Ausgabe. Berlin: 2012

3 Wagner D. Münchner Nomenklatur II für die gynäkologische Zytodiagnostik. Acta Cytol 1990; 34: 900-901

4 Griesser H, Breinl H, Jordan B. Münchner Nomenklatur III: Gynäkologische Dysplasien werden klar zugeordnet. Dtsch Ärztebl 2014; 111: 15, A-640/B-550/C-530

5 Kassenärztliche Bundesvereinigung. Qualitätssicherungsvereinbarung Zervix-Zytologie: Aktualisierte Fassung tritt zum 1. Januar 2015 in Kraft. Dtsch Ärztebl 2014; 111: 33-34, A-1434/B-1238/C-1178

6 Schneider A, Hillemanns P. Comments on the publication of Munich nomenclature III by the Cytology Coordination Conference. Geburtsh Frauenheilk 2014; 74: 242-243

7 Kühn W, Gieseking F, Menton M et al. Remarks by the Board of the Study Group for Cervical Pathology and Colposcopy on the "Comments on the publication of Munich nomenclature III by the Cytology Coordination Conference" by A. Schneider and P. Hillemanns (Geburtsh Frauenheilk 2014; 74: 242-243). Geburtsh Frauenheilk 2014; 74: 634-635

8 Griesser H, Marquardt K, Jordan B. Remarks on the "Comments on the publication of Munich nomenclature III by the Cytology Coordination Conference" by A. Schneider and P. Hillemanns (Geburtsh Frauenheilk 2014; 74: 242-243). Geburtsh Frauenheilk 2014; 74: 636-636

9 Schneider A, Hillemanns P. Response to the letters from W. Kühn et al. and H. Griesser, K. Marquardt and B. Jordan on "Comments to the publication of Munich nomenclature III by the Cytology Coordination Conference" (Geburtsh Frauenheilk 2014; 74: 242-243). Geburtsh Frauenheilk 2014; 74: 637-638 
10 Bundesgesundheitsministerium. Nationaler Krebsplan. Handlungsfelder, Ziele und Umsetzungsempfehlungen. 2012. Online: https://www. bundesgesundheitsministerium.de/fileadmin/dateien/Publikationen/ Praevention/Broschueren/Broschuere_Nationaler_Krebsplan_-_Handlungsfelder_Ziele_und_Umsetzungsempfehlungen.pdf; last access: 10.03.2015

11 Kassenärztliche Bundesvereinigung. Vereinbarung von Qualitätssicherungsmaßnahmen nach $\S 135$ Abs. 2 SGB V zur zytologischen Untersuchung von Abstrichen der Cervix uteri (Qualitätssicherungsvereinbarung Zervix-Zytologie). Dtsch Ärztebl 2007; 104: 36, A-2446/B2162/C-2094

12 Griesser H, Marquardt K, Jordan B et al. Zervix-Zytologie. Das Prozedere bei auffälligen Befunden. Kommentar zur Münchner Nomenklatur III. Frauenarzt 2015; 56: 10-13

13 Solomon D, Davey D, Kurman R et al. The 2001 Bethesda System: terminology for reporting results of cervical cytology. JAMA 2002; 287: 2114-2119

14 Kjaer SK, Breugelmans G, Munk C et al. Population-based prevalence, type- and age-specific distribution of HPV in women before introduction of an HPV-vaccination program in Denmark. Int J Cancer 2008; 123: $1864-1870$

15 Deleré Y, Schuster M, Vartazarowa E et al. Cervicovaginal self-sampling is a reliable method for determination of prevalence of human papillomavirus genotypes in women aged 20 to 30 years. J Clin Microbiol 2011; 49: 3519-3522

16 Moroney JW, Zahn CM, Heaton RB et al. Normal endometrial cells in liquid-based cervical cytology specimens in women aged 40 or older. Gynecol Oncol 2007; 105: 672-676

17 Simsir A, Carter W, Elgert P et al. Reporting endometrial cells in women 40 years and older. Assessing the clinical usefulness of Bethesda 2001. Am J Clin Pathol 2005; 123: 571-575

18 Griesser H, Marquardt K, Jordan B et al. Gynäkologische Zytodiagnostik der Zervix. Münchner Nomenklatur III. Frauenarzt 2013; 11: 10421048
19 Eversole GM, Moriarty AT, Schwartz MR et al. Practices of participants in the College of American Pathologists interlaboratory comparison program in cervicovaginal cytology, 2006. Arch Pathol Lab Med 2010; 134: 331-335

20 Östor AG. Natural history of cervical intraepithelial neoplasia: a critical review. Int J Gynecol Pathol 1993; 12: 186-192

21 Kiviat $N$. Natural history of cervical neoplasia: overview and update. Am J Obstet Gynecol 1996; 175: 1099-1104

22 Duggan MA, McGregor SE, Stuart GC et al. The natural history of CIN I lesions. Eur J Gynaecol Oncol 1998; 19: 338-344

23 Moscicki AB, Cox JT. Practice improvement in cervical screening and management (PICSM): symposium on management of cervical abnormalities in adolescents and young women. J Low Genit Tract Dis 2010; 14: $73-80$

24 De Jonge M, Busecke G, Heinecke A et al. Human papillomavirus genotype distribution in cytologically screened women from northwest Germany. Acta Cytol 2013; 57: 591-598

25 Moscicki AB, Palefsky J, Gonzales J et al. Human papillomavirus infection in sexually active adolescent females: prevalence and risk factors. Pediatr Res 1990; 28: 507-513

26 Moscicki AB, Schiffman M, Burchell A et al. Updating the natural history of human papilloma virus and anogenital cancers. Vaccine 2012; 30: F24-F33

27 Bray F, Carstensen B, Møller H et al. Incidence trends of adenocarcinoma of the cervix in 13 European countries. Cancer Epidemiol Biomarkers Prev 2005; 14: 2191-2199

28 Löning T, Riethdorf L, Köbel M. Diagnose und Differenzialdiagnose des zervikalen Adenokarzinoms. Pathologe 2011; 32: 505-513

29 McCluggage WG. New developments in endocervical glandular lesions. Histopathology 2013; 62: 138-160

30 Fetters MD, Fischer G, Reed BD. Effectiveness of vaginal Papanicolaou smear screening after total hysterectomy for benign disease. JAMA 1996; 275: 940-947

31 Sirovich $B E$, Welch $H G$. Cervical cancer screening among women without a cervix. JAMA 2004; 291: 2990-2993 